\title{
MANFREDO TAFURI AND THE CRITIQUE OF REALISM
}

\section{A B S T R A C T}

One of the main themes of Manfredo Tafuri's historical work, whether he was analyzing Renaissance, Enlightenment or the $20^{\text {th }}$ century architecture, has been that of trying to illustrate the distance between architect's work and reality.

This topic is also the premise, the introductory theoretical frame for his critical and historical discourses that are inherent to his "critique of realism": a critique that was expressed in the essay Architettura e Realismo [Architecture and Realism], published in 1985. A text that represented the conclusion of Tafuri's observation on the Italian postwar architectural culture. In this essay the Italian neorealism became the object of a rather unique historical contextualization, the object of Tafuri's deep critique and, ultimately, of his demystification. 
"It is, in fact, the inherent opposition within all modern art: those who search into the very bowels of reality in order to know and assimilate its values and wretchedness; and those who desire to go beyond reality, who want to construct ex novo new realities, new values, and new public symbols."

Manfredo Tafuri, Architecture and Utopia, 1973.

One of the main themes of Manfredo Tafuri's historical work, whether he was analyzing Renaissance, Enlightenment or the twentieth century architecture, has been that of trying to illustrate the distance between architect's work and reality; or, if we read that back in the original terminology of the 1960s and 1970s, the relationship between the architects mentality, or better, their ideology and the "capitalist development". One could even say that Tafuri's meticulous examination of the nature of architect's intellectual work, was based on the relationship between these two, sometimes opposite poles: the architectural project and reality, the architect's ambition - since the Enlightenment - to define the form and the growth of the city and the effective outcomes of his efforts.

Tafuri's questions were in fact very simple, yet quite ruthless: what kind of relationship establishes the architectural project with the city in terms of its material and immaterial transformations? How far goes the architect's ambition to operate within the real conditions? And how much is he - consciously or not - hiding beyond the curtains of utopias, beyond the inventions of artificial languages, beyond the fascination for the autonomy of architecture, in order to deliberately avoid speaking about the concrete circumstances that distinguish his professional activity? Which kind of attitude lies beyond his architectural gestures, his languages, his inventions? And, especially, why architects still cultivate the ambition, expressed mainly through their theories, to change reality through the architectural project? Why do they need to build theories, to create complex conceptualizations of their work, when it has become clear, almost since the beginning of the industrial revolution, that the "capitalistic development" has taken away from architecture, from "any ideological prefiguration", the task of changing society? ${ }^{2}$ When it has become clear that reality (the capitalist development) runs faster than any architect's will or idea to change society, and when it is already clear that it runs without any concern about the architects will to control, dominate or even address reality? And when it is clear that architecture is simply an "oggetto trascurabile": "a negligible, useless object" in the city. ${ }^{3}$ 
It is not the aim of this article to answer these questions, or to deal with the origins, the contexts and the reasons for the theoretic issues raised by Tafuri, during his rich historical and theoretical work. These questions represent rather a premise, an introductory theoretical frame for the critical and historical discourses that are inherent to Tafuri's "critique of realism". A critique that was expressed by the Roman historian in one specific text - Architettura e Realismo [Architecture and Realism] - published in 1985 in the Triennale exhibition catalogue Le avventure della realtà (1750-1980) [The Adventures of Reality], edited by Vittorio Magnago Lampugnani. ${ }^{4}$ Basically, the essay meets the objectives of the publication: to trace back in history the origins and the genealogy of some of the most important topics that characterized the modernity in architecture, such as rationalism, technicality, organicism, expressionism and realism. Tafuri's text is a concise reflection on the genealogy of the realism $(S)$ in architecture since the $19^{\text {th }}$ century, and in fact concentrates the results of his lifelong research, which he undertook first in Rome and later in Venice, where he was leading the renowned "Dipartimento di Analisi, Critica e Storia dell'Architettura" at the IUAV, renamed later to "Dipartimento di Storia dell'architettura". The essay traces the vicissitudes of the many different historical contexts, that were the object of Tafuri's analysis from the beginning of the 1960 s till $1984 .^{5}$

\section{THE FORMATIVE YEARS AND THE NEOREALISM}

Before entering into specific contents of Tafuri's critique of realism in architecture, it is important to recall some aspects of his intellectual biography in order to better contextualize his text, within his contemporary architectural and cultural debate. Since every critical and historiographical attitude needs a proper historical contextualization, it becomes especially important in the case of Tafuri, a historian that was particularly, if not obsessively, linked to his present. Even his determination in observing and estimating the distance between reality and architect's work, can be ascribed to a specific reaction to the context of his intellectual formation.

Tafuri attended the Faculty of Architecture in Rome, where he graduated in 1959 , a context that was strongly influenced by the debate on the reconstruction of postwar Italy. The process of reconstruction was a pivotal moment for the Italian culture, in which - one could definitely say - the modernity of Italian architecture manifested itself at a wider national level. A modernity that was not anymore, like in the 1930s, an "elite" phenomena, that characterized the main Italian cities and specific industrial or cultural circles, but conquered mostly all levels of Italian society and all geographic areas of its multifaceted territory. ${ }^{6}$ 
The postwar Italian architectural culture faced many structural difficulties. On one side it had to deal with concrete, material problems: the economic collapse, the dramatic social and housing problems, the technological backwardness of the Italian building industry, the necessity of recreating the construction industry from the foundations. At the same time, it had to face the unique cultural challenges: besides rebuilding the country, the Italian culture had by all available means to overcome the legacy of Fascism. Besides the cultural, intellectual and professional legacy, that which had to be changed radically was the architectural language, the traditional relationship between architecture and the city, the nature of teaching architecture, the political and cultural role of intellectuals and the role of criticism. But what represented the biggest impediment was the absolute lack of models, of cultural references, especially international, from which to draw inspiration.

The existing examples, or models, that characterized the 1920s and the 1930s in Italy, were absolutely unfitting and had to be erased from the postwar mentality: on one side the academic architecture, inspired by neoclassic tendencies that characterized the Fascist architecture, both in linguistic and spatial terms; on the other side, the legacy of functionalism, which was simply unthinkable in the context of the immediate postwar years. In terms of architectural language, it was unimaginable to organize the reconstruction of the country on the premises of pure abstraction, or with the institutionalized historicist languages; in terms of urban planning, it was clear that the models proposed in the 1920s and the 1930s were definitely inadequate, both the monotone organization of the early modernist urban designs, and the monumentality that characterized the excessive forms of the Fascist Italy. In this sense, immediately after the war, Italy opened
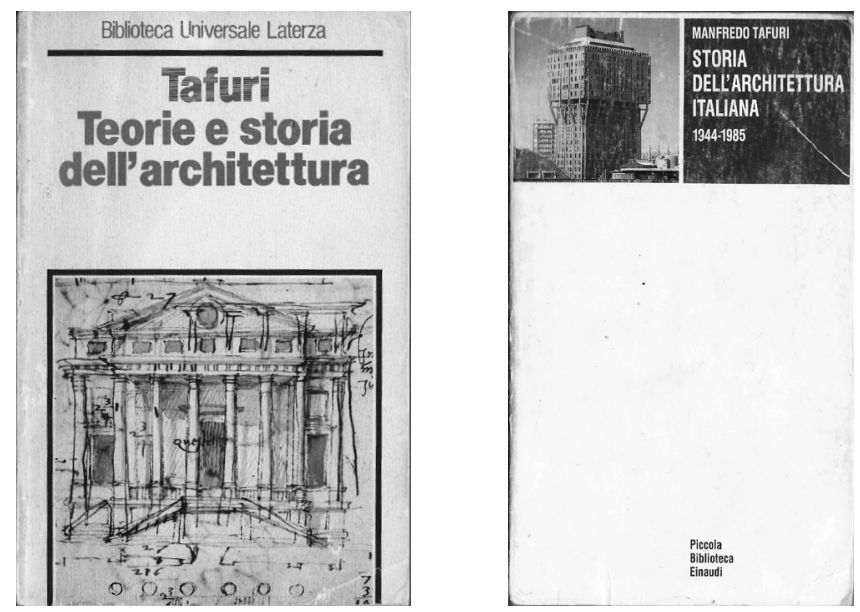

Figure 1-2. Cover of M. Tafuri, Teorie e storia dell'architettura (Bari: Laterza, 1968) 
an extensive critique of the modernist legacy, that characterized mostly all its professional contexts and its cultural institutions. The critical activity of Bruno Zevi and Ernesto Nathan Rogers, the architecture of Mario Ridolfi, Franco Albini or Ignazio Gardella - while having different architectural inspirations and outcomes - had the common denominator of rethinking the linguistic and spatial heritage of the prewar culture - the optimization of neoclassicism and the legacy of functionalism. In parallel with the international trends, a new chapter in the evolution of modernity in architecture in Italy and Europe had to be developed.

It could be said in simplified terms that, the Italian architects proposed one main direction, or rather, one model, for the national reconstruction and the renewal of its cultural identity from its foundations: the so-called neorealism, namely the recovering of spatial and formal themes from the rural, popular traditions. This aspiration for the invention of a new language, based on the inclusion of the rich Italian heritage in a modernist project, functioned from the beginning as a successful ideal for a large part of the Italian architectural culture. Neorealism - as it is widely known - was a magic moment in Italian culture: art, literature, sociology, philosophy, urban geography, cinema and architecture shared the idea of turning the attention to the "simple man", to the "simple things", to the new account of reality. Almost the entire Italian inteligencija participated, in a collective multidisciplinary effort, in the reconstruction of the country, based on the myth of the spontaneous, traditional culture.

The formative years of Manfredo Tafuri were characterized by the Italian modernization through neorealism. And, like all architects of his generation, at the beginning of the 1960s, he was called to confront himself with the results of the reconstruction, questioning its outcomes. Italy, in the late 1950s and early 1960s entered the so-called miracolo economico [economic miracle], achieving its first widespread well-being, with all its contradictions. The epic intentions of the Italian neorealist culture - of shifting the nation from an agrarian society and from a dictatorial regime to a democratic future characterized by a mild and controlled impact of industrialization, and a peaceful, non- frustrating collision with the life in the city - have been placed under scrutiny: the architectural effort of the committed intellectuals showed itself as quite marginal, confined to small partial interventions in the urban reality. However, the growth of the cities became uncontrollable, and its administration unmanageable, and the contradictions increased. Also increased were the frustrations of the architects, unable to manage the complexity of the urban and social reality and to achieve the purposes dictated by their own intellectual aspirations. Reality became increasingly chaotic, disjointed. At the same time the political crisis became 
finally evident, especially in the fields of urban and city planning: it became clear - as it was promptly shown in "Le mani sulla città" [Hands Over the City], one of the masterpieces of Italian postwar cinematography ${ }^{7}$ - the future of the cities was mostly held in the hands of land and building speculators, supported by the interests of associations, constituted by politicians and semilegal or illegal organizations.

This situation strongly affected the second postwar generation that, at the beginning of the $1960 \mathrm{~s}$, started to face the project of the reconstruction of the Italian society, with the belief in the possibility of conditioning the reality. This will represent the standpoint for the generation of Aldo Rossi, Carlo Aymonino and Vittorio Gregotti (all born between 1926 and 1931) and their activity in the field of design and architectural criticism. On the contrary, Tafuri's path (born in 1935) was mainly historical and critical: starting from difference between the capitalist development and architects ideology, he would begin a profound analysis of the history of architectural theories, its developments and contradictions, starting from the roots of modern architectural thought: the Renaissance.

And, of course, the Italian neorealism became the object of his analysis, of his deep critique and, ultimately, of its demystification. Since his first writings on the main actors of the reconstruction (Ridolfi, Zevi, Quaroni, Samonà) Tafuri's task was to dissect the realist mentality, to understand all the cultural stages of this attitude, in order to explain its aims, its success (that were detected mostly in cinematography and literature, and less in the field of architecture and urban planning), but also to explain the reasons of its failure. ${ }^{8}$

Besides this fundamental analysis of the Italian postwar culture, Tafuri's essay Architettura e realismo is interesting also at a larger methodological level. It proposes a large and rather unique contextualization of the Italian realism within the international architectural culture. Tafuri proposed a diachronic, transversal dialogue between neorealism and other contexts within which the realistic attitudes emerged during the twentieth century.

\section{ARCHITETTURA E REALISMO}

In order to better understand Tafuri's intentions, it is useful to retrace the main chapters of his essay and to emphasize his conclusions. The first context that catches his attention is the early revolutionary Russia. He identifies strong realistic attitudes in the projects of Andrej Belogrud, especially in his proletarian House (1918), and in the first experiments of Ilja Golosov and Konstantin Melnikov (his housing projects of the early 1920s, the competition 
project for a crematorium in 1925): rustic elements, izba-like roofs, naïf gestures. Motifs of the peasant world, variously declined, enter into formal expression of architects, that are usually acclaimed as pioneers of the new languages. These first projects of the young Russian avant-garde, in a process of erasure of eclecticism and escaping from the legacy of neoclassicism, in fact, propose new architectural references to the "reality", sanctifying the references of the new political order, entirely based on the consensus of the workers and the peasant population. "The eternal farmer", a "subject that refers to a nostalgia of the original, the ancestral, the absolutely pure Edenic happiness", 9 are all themes that can be found in the vast intellectual context of the first revolutionary years, in architecture, art, literature, like in the first work of Malevič, in Lissitzky's graphic interpretations of Jewish fairytales, in the trans-mental poetry of Kručenych and Hlebnikov, or in the revision of the painting techniques from the ancient Russia by Florenskij and Favorskij.

Tafuri here proposes his first demystification of the avant-garde, and of the modernist movements in general: "Between Realism and avant-garde there is a moment of transition, an uncertain boundary that participates ambiguously in two opposing ideals". ${ }^{10}$ The "taste" for realism marked even the projects of the most prominent figures of the artistic and architectural revolution, the figures that in the wake of abstractionism fought against the historical and traditional approaches. The approaches that are in fact - by definition - the premises of any realism. Even Le Corbusier ends up in Tafuri's reading of the heroic years of modernism: promptly, the Roman historian notes how the rural motifs of Maison Errazuriz (1930) coexist with the most experimental phase of his architecture.

The architecture of the Soviet Union was the object of Tafuri's courses and seminars at IUAV in 1971-72 and 1976-77. ${ }^{11}$ During his entire career for him his seminars, were a precious laboratory, a context where his researches were verified through teaching and discussions. The Soviet Union was also the subject of his field trip, number of his essays and researches, ${ }^{12}$ and the subject of two important conferences that he developed with a group of historians at different occasions at the Department of History of Architecture at IUAV: Socialismo, città, architettura, URSS 1917-1937, il contributo degli architetti europei and USSR 1917-1978: la ville, l'architecture (with Jean-Louis Cohen, Marco De Michelis). ${ }^{13}$

The second case-study of Tafuri's investigation of realism is the socialdemocratic Vienna, and in particular the years between 1918 and 1934, when the enlightened authorities of the new Austrian democracy, based on 
the ideologies of Austro-Marxism, promoted the realization of an enormous quantity of housings for workers. In these complexes, from the first realizations of Hubert Gessner to the celebrated Karl-Marx-Hof by Karl Ehn, Tafuri identifies a permanent presence of models coming from the Austrian architectural tradition: on one side the national-popular idioms (as in the previous Russian case-study), on the other side the spatial organization of the late-empire urban projects (most of the architects of Red Vienna were Otto Wagner pupils).

In his vision, the political and cultural Austro-Marxist project accomplished a new city model, that evoked concrete signs of "socialist realism". In achieving these almost mythological results, the Austrian architectural culture used traditional architectural expressions, chose the "semantic of the realist novel": an alternative path to the parallel German experiences in Frankfurt or Berlin, or to the futuristic dreams of the radical projects of Bruno Taut, Le Corbusier or other European avant-gardes. The Red Vienna experience for Tafuri is the demonstration of the relativity of the architect's utopian dreams: "Utopia has no place in a city that chooses to become 'home', a home for a working class with a 'conscience' and redeemed in its values of Brüderlichkeit [brotherhood]". ${ }^{14}$ This "realized utopia" seems to have escaped from the hands of the architect, from the consideration of the twentieth century architect: bow-windows, moldings, decorations, floral motifs and the like are for Tafuri the elements that mediate the political message with the urban impact of these architectures, the new models of community life with the population's need for domesticity: "The values of 'good old Mr. Biedermeier' are taken from their isolation and delivered to the people." 15 Although not expressly stated by Tafuri, the Red Vienna's architecture was also a demonstration of the relativity of the language imposed by the modernist architects understood as the exclusive language of modernity. The realization of a new city model, as the product of an enlightened association between politicians and professionals, that meets the appreciation of the wider population, does not match the architectural aspiration of the formally most progressive architects of the 1920s.

Furthermore, those who want to recognize a precise and unified ideological background in the phenomenon of realism will be disappointed. Tafuri demonstrates how populism takes shape - in our case through architecture - with many facets, with different forms and languages, causing difficulties for historians. And, above all, he is interested in the mental attitude of these planned processes that are anything but homogeneous. The tenuous thread that connects all these contexts that deal with the phenomena called realism, is characterized by one strong common aspect of the architectural message: 
Tafuri defines it as the general "reaction to the modern", the passion for the "original", the taste for the "traditional", anti-modernism. The story of Red Vienna was well analyzed in his IUAV-Seminar "Great Vienna": From the Formation of the Hapsburg Myth to the Crisis of Austro-Marxism, ${ }^{16}$ held in 1977-1978, and in his book Vienna rossa: la politica residenziale nella Vienna socialista 1919-1933 (published in 1980). ${ }^{17}$

Another curious case study in Tafuri's narration is represented by the architecture of the New Deal, and in particular, the planning experiences of the Tennessee Valley Authority. The Venetian department of history in the 1970s dedicated a lot of attention to this case study, recognizing a quite unique American experience of integrated planning in combination of the planning of production, the regulation of the river flows, the rehabilitation of agricultural land, the regional electrification and the construction of cities and housings..$^{18}$ Tafuri here concentrates his attention on the small village of Norris-town, designed by the town planner and landscape designer Earle Draper, a village made of the anonymous houses scattered in the natural setting, designed for workers of the dam, whose form was inspired by the elementary pioneer houses of the eighteenth century. Tafuri places Norris-town in the same category with the previous examples, as a context where the search for the real matches the search for the ancestral messages and images. Norris-town in his eyes is an evidence of the planning philosophy of the Tennessee Valley Authority: a planning that is based on a model of society that is an antithesis to "the bad metropolis" of Wall Street. The persistent ruralism and the naturalism of houses scattered in the landscape, for Tafuri, speak about the original "human qualities" that had to be evoked "in the operation carried out in this region". ${ }^{19}$ An operation of semantic realism, a product of a collective desire to detach from urban reality that ultimately, for Tafuri, reveals a "dangerous" anti-urban attitude. The American architecture and the anti-urban ideologies were subjects of Tafuri's first courses at the IUAV (Architecture, City and "Plan" in America and History of Anti-Urban Ideology), ${ }^{20}$ while during his entire career he continued to invest his energy in understanding the different characteristics of the American architectural context, publishing essays and various book chapters. ${ }^{21}$

\section{THE CONTRADICTIONS OF NEOREALISM}

Yet, Tafuri's excursus is not casual. The Tennessee Valley Authority projects represented one of the models of the Italian postwar reconstruction: these experiments were already known and presented to the Italian architectural culture by Bruno Zevi, a critic whose activity in the 1940s and 1950s was 
extremely important in spreading in Italy the experiments in American and Anglo-Saxon planning in general. Tafuri recalls how American models have been studied both in spatial and in sociological terms, for the realization of the neighborhoods in late 1940s (UnrraCasas, Roma) and early 1950s (La Martella, Tiburtino Rome). As already mentioned, the essence of Italian neorealism, the ethic of the reconstruction of the country develops in parallel with a substantially anti-urban vision of the city, within the myth of the neighborhood, and with an architectural language distant from the modernist aims.

Language and attitudes that Tafuri reconnects with some realizations that characterized the Fascist Rome, especially the architectures of Innocenzo Sabatini, and his marvelous complexes from the 1920s - the Garbatella district, the housing in Piazza d'Armi, 1925 - defined as "the architecture parlante for low classes". ${ }^{22}$ The architects of the residential Rome expand, like it was the case in Vienna, the petty bourgeois domesticity to the masses, and accomplish an architectural reaction to modernism: for Tafuri they "act as pedagogues", with the aim of creating the sense of "community", using motifs in which the inhabitants can generally "recognize" themselves. ${ }^{23}$

Recognition, traditional motives, the utopia that confronts the city and become "just a home", the traditional roots in avant-garde mentality - all these, quite unpredicted facts, dominate the different realisms in the 20th century, and in fact describe quite well also the backgrounds of Italian Neorealism: the main subject of Tafuri's essay.

Therefore, one of the main assumptions of Architettura and realismo is that the term Realism is quite an abstract category, which always has to be redefined, depending on the context where the realist attitudes manifest. Realism touches all areas of modernity transversally, and not always in intelligible ways. And it is difficult to grasp its different expressions, to explain its manifestations, because realisms are not strictly spontaneous phenomena: on the contrary, they are always the result of a project, which is a product of a historical construction. The necessity for a realist attitude is felt by the authors and by the addressees of architecture, but at the same time they are the product of an artificial invention. An invention, as Tafuri explained through the example of Italian neorealism, which can have straight relations to specific aspects of its neglected past (Fascism): the collectivization of the architectural and spatial experience, the identification in a community. 
In his complex analysis that reveals several contradictions of the phenomena, Tafuri offers only one assurance: the unique common element to the different realisms lies in their manifestation for an "exasperated need for communication": 24 architecture is a formal evidence of the necessity of the promoters, of the authors and of the population, to communicate their necessity of mirroring themselves in an idea, in a common value.

But, there is a price to pay for this necessity to communicate, and that is the appeal to tradition. For Tafuri, to recall the rural, the traditional, the "good old times", is no longer an innocent operation. This attitude reveals aspects of a profound anti-modernism: "The Italian neorealism projects a desire of regeneration based on a sentimental image of a national reality that hides the need to expiate some ancient guilt". ${ }^{25}$ In other words, the research for the roots that characterizes these ethical commitments denotes a regressive ideology: the architectural outcomes of these realisms show how elusive the confrontation is with the mass society, with the urbanity and, ultimately, with the reality itself.

\section{THE “SNOBBISH GAMES" OF POSTMODERNISM}

As often occurred with Tafuri's historical and theoretical analysis, they were rarely separated from the contemporary debates. In fact, his critique of realism is not isolated from the historical case study, but on the contrary is written looking at some architectural trends that were monopolizing the Italian and international architectural scene in the 1980s: the movements of New Urbanism in the United States, the criticism of Paolo Portoghesi, Robert Stern and Charles Jencks and in general the phenomena of Postmodernism in architecture. Tafuri's consideration of these trends was extremely negative. He was strongly opposing the banal recall of historical styles that characterized the architecture of Postmodernism - in this sense, his polemics with Portoghesi is emblematic ${ }^{26}$ - and the outcomes of Portoghesi's curatorial project Strada Novissima, at the 1980 Venetian Biennale. In the critique of modernism, the appeal for a liberation from the "linguistic cages" of the avant-garde, the re-enactment of the languages of the past, all of which were advocated by the theoreticians of the new eclecticism, Tafuri saw parallels with the realist attitudes that characterized the twentieth century. However, he promptly distinguished Postmodernism as a trend, completely emptied from any social content, without any correspondence between social desire and architectural outcome and condemned it as a product of pure "snobbish games". ${ }^{27}$ 
NOTES

1

2

Manfredo Tafuri, Progetto e utopia, (Bari: Laterza, 1973), trans. Architecture and Utopia, (Cambridge: MIT Press, 1976), 24.

These theses are expressed both in Tafuri, Teorie e storia dell'architettura, (Bari: Laterza, 1968), trans. Theories and History of Architecture, (New York: Harper \& Row, 1980) and Progetto $e$ utopia.

See chapter two "L'architettura come 'oggetto trascurabile' e la crisi dell'attenzione critica," in Teorie e storia dell'architettura, 95-120. See also Pier Vittorio Aureli, "Recontextualizing Tafuri’s Critique Of Ideology," Log 18 (2010): 89-100.

Manfredo Tafuri, “Architettura e realismo," in L'avventura delle idee nell'architettura: 17501980, exhibition catalogue edited by Vittorio Magnago Lampugnani, XVII Triennale di Milano (19 may-3 june 1985), (Milano: Electa, 1985), 123-147.

In 1984, Tafuri publishes his important synthesis of the postwar italian architecture: Storia dell'architettura italiana 1945-84 (Torino: Einaudi, 1984).

For a brief introduction to the Italian postwar context see: Tafuri, Storia dell'architettura italiana, op.cit.; Amedeo Belluzzi, Claudia Conforti, Architettura italiana 1944-1984, (Roma: Laterza 1985), Giorgio Ciucci, Francesco Dal Co, Architettura italiana del Novecento, (Milano: Electa 1990); Storia dell'architettura italiana. Il secondo Novecento, ed. Francesco Dal Co, (Milano: Electa, 1997); Maristella Casciato, "Neorealism in Italian Architecture," in Anxious modernisms: experimentation in postwar architectural culture, ed. S. Williams Goldhagen and Rejean Legault (Cambridge: Mit Press, 2000), 25-53; Bruno Reichlin, "Figures of Neorealism in Italian Architecture (part 1)," Grey Room 5 (Autumn 2001), 78-101; Reichlin, "Figures of Neorealism in Italian Architecture (part 2)," Grey Room 6 (Winter 2001), 101-133; Sergio Poretti, Modernismi italiani: architettura e costruzione del Novecento, (Roma: Gangemi 2008). "Le mani sulla città" [Hands over the city] directed by Fracesco Rosi was released in 1963. It showed, in the years of the biggest economic and urban growth, the effective functioning of the public works, and the collusion between the state and the "underworld".

Manfredo Tafuri, "La vicenda architettonica romana: 1945-1961," Superfici. Problemi di architettura e tecnologie edili. Rivista dei pavimenti, rivestimenti e coperture, 5 (april 1962): 2042; encyclopedic entries "Architettura", "Ignazio Gardella", "Mario Ridolfi”, "Bruno Zevi”, in Enciclopedia italiana di scienze, lettere ed arti, (Roma: Istituto dell'Enciclopedia Italiana, 194960); Tafuri, "Ludovico Quaroni e la cultura architettonica italiana," Zodiac, 11 (1963): 130-45, republished in Ludovico Quaroni e lo sviluppo dell'architettura moderna in Italia, (Firenze: Edizioni di Comunità, 1964).

My translation. Tafuri, Architettura e realismo, 124.

Ibid.

Respectively Avanguardie, città e pianificazione nell'Unione Sovietica (Avant-garde, cities and planning in Soviet Union) and Avanguardia e architettura: le avventure nel linguaggio nell'arte contemporanea (Avant-garde and architecture: the Adventures of Language in Modern Art). The contents of the seminars are collected by Luca Scapin at the Archivio Progetti of the University IUAV in Venice. For a complete list see Andrew Leach, Manfredo Tafuri: choosing history (Ghent, A\&S Books 2007).

The architecture of Soviet Union was the object of Francesco Dal Co's diploma thesis, Tafuri's first venetian student and later collegue: Francesco Dal Co, Tre saggi sull'architettura sovietica, 1917-37 (Venice: Iuav 1970).

Socialismo, città, architettura: URSS 1917-1937. Il contributo degli architetti europei, (Roma: Officina 1971); URSS 1917-1978: la ville, l'architecture, ed. Jean-Louis Cohen, Marco De Michelis, Manfredo Tafuri, (Roma, Paris: Officina, L'Equerre, 1979).

My translation. Tafuri, Architettura e realismo, 126.

Ibid, 127.

Orig. "Grande Vienna": Dalla formazione del mito asburgico alla crisi dell'austromarxismo, IUAV, 1977-78. 
Vienna rossa: la politica residenziale nella Vienna socialista, 1919-1933, ed. Manfredo Tafuri (Milano, Electa, 1980). His earlier treatment of the subject appeared as "Austromarxismo e città: 'Das Rote Wien'”, Contropiano 2 (July 1971): 259-311.

La città americana dalla guerra civile al New Deal, essays by G. Ciucci, F. Dal Co, M. Manieri Elia, M. Tafuri (Roma: Laterza, 1973).

My translation. Tafuri, Architettura e realismo, op. cit, p. 132.

Architettura, città e "piano" in America (1500-1970) (1969-70), Storia dell'ideologia antiurbana (1972-73); in subsequent years he dedicated other three seminars on american architecture: Struttura e architettura della città terziaria in America (1850-1973) (1973-74), Lo sviluppo urbano negli Stati Uniti e il problema del housing (1780-1974) (1974-75), Il grattacielo e la struttura terziaria in America e in Europa (1850-1975) (1975-76).

Especially Manfredo Tafuri, La sfera e il labirinto: avanguardie e architettura da Piranesi agli anni '70, (Torino, Einaudi 1980). For a complete bibliography see Anna Bedon, Guido Beltramini, Pierre-Alain Croset, "Una prima bibliografia”, Casabella 619-620 (1995): 170-175; Leach, op.cit., 275-310.

Ibid.

Ibid., 123.

Ibid., 133.

See chapter "La 'gaia erranza': ipermoderni (postmoderni)," in Storia dell'architettura italiana, 230-234. 619-620 (1995), 170-175.

Belluzzi, Amedeo and Claudia Conforti. Architettura italiana, 1944-1984, (Roma: Laterza 1985).

Casciato, Maristella. "Neorealism in Italian Architecture." In Anxious modernisms: experimentation in postwar architectural culture, ed. S. Williams Goldhagen and Rejean Legault (Cambridge: Mit Press, 2000).

Ciucci, Giorgio and Francesco Dal Co. Architettura italiana del Novecento, (Milano: Electa 1990) Storia dell'architettura italiana. Il secondo Novecento, ed. Francesco Dal Co, (Milano: Electa, 1997)

La città americana dalla guerra civile al New Deal, essays by G. Ciucci, F. Dal Co, M. Manieri Elia, M. Tafuri (Roma: Laterza, 1973).

Leach, Andrew. Manfredo Tafuri: choosing history (Ghent, A\&S Books 2007).

Poretti, Sergio. Modernismi italiani: architettura e costruzione del Novecento (Roma: Gangemi 2008).

Reichlin, Bruno. "Figures of Neorealism in Italian Architecture (part 1)." Grey Room 5 (Autumn 2001), 78-101 
Reichlin, Bruno. "Figures of Neorealism in Italian Architecture (part 2)." Grey Room 6 (Winter 2001), 101-133.

Socialismo, città, architettura: URSS 1917-1937. Il contributo degli architetti europei (Roma: Officina 1971).

Tafuri, Manfredo. Progetto e utopia, (Bari: Laterza, 1973), trans. Architecture and Utopia, (Cambridge: MIT Press, 1976), 24.

Tafuri, Manfredo. Teorie e storia dell'architettura, (Bari: Laterza, 1968), trans. Theories and History of Architecture, (New York: Harper \& Row, 1980)

Tafuri, Manfredo. "Architettura e realismo." In L'avventura delle idee nell'architettura: 17501980, exhibition catalogue edited by Vittorio Magnago Lampugnani, XVII Triennale di Milano (19 may-3 june 1985), (Milano: Electa, 1985).

Tafuri, Manfredo. Storia dell'architettura italiana 1945-84 (Torino: Einaudi, 1984).

Tafuri, Manfredo. "La vicenda architettonica romana: 1945-1961." Superfici. Problemi di architettura e tecnologie edili. Rivista dei pavimenti, rivestimenti e coperture, 5 (april 1962), 20-42

Tafuri, Manfredo. Ludovico Quaroni e lo sviluppo dell'architettura moderna in Italia (Firenze: Edizioni di Comunità, 1964).

Tafuri, Manfredo. La sfera e il labirinto: avanguardie e architettura da Piranesi agli anni '70 (Torino, Einaudi 1980).

URSS 1917-1978: la ville, l'architecture, ed. Jean-Louis Cohen, Marco De Michelis, Manfredo Tafuri, (Roma, Paris: Officina, L'Equerre, 1979).

Vienna rossa: la politica residenziale nella Vienna socialista, 1919-1933, ed. Manfredo Tafuri (Milano, Electa, 1980). 


\section{ARHITEKTURA UTOPIJA REALIZAM: TEMATSKI OKVIR Ljiljana Blagojević}

Termin ili koncept realizma re-aktuelizovan je u skorašnjim teorijskim debatama od rasprava u filozifiji i estetici do onih u teoriji i praksi arhitekture. Počev od 2000. godine, arhitektonski diskurs se često bavi širokim spektrom srodnih pitanja koja proističu iz post-kritičkih rasprava o utopijanizmu i realizmu i mogućnosti jednog "utopijskog realizma", kako je to sugerirao Rajnhold Martin (2005). Rasprave o realizmu ponovo rezoniraju u arhitektonskoj teoriji kao odraz Manifesta novog realizma, filozofa Mauricija Ferarisa iz 2011 godine. Pitanja realizma naspram postmodernizma, "novog realizma" koji nastaje na pepelu post-modernizma, kritički i operativni pojmovi realizma i slično, postavljana su kako kroz prakse savremene arhitekture tako i kroz preispitivanje realizma i socijalističkog realizma u istoriji i teoriji arhitekture. Postavka tematskog okvira u ovom članku SAJ: Arhitektura Utopija Realizam ima za cilj da produbi tekuće rasprave o odnosima arhitekture sa realizmom i utopijom.

KLJUČNE REČI: ARHITEKTURA, UTOPIJA, REALIZAM, AUR MEĐUNARODNA NAUČNA KONFERENCIJA, UNIVERZITET U BEOGRADU - ARHITEKTONSKI FAKULTET

\section{UTOPIJA STVARNOSTI. REALIZMI U ARHITEKTURI IZMEĐU IDEOLOGIJE I FENOMENOLOGIJE Silvia Malcovati}

Predložen povodom Prvog Kongresa sovjetskih pisaca u Moskvi 1934 godine, pojam realizma u teorijskim raspravama o arhitekturi u ranim tridestim godinama dvadesetog veka, izgleda kao dvosmisleni pojam, koji se koleba između idealizma i ideologije, inovativnog istraživanja i istoricističkog formalizma. Neuspeh socijalističkog realizma i kriza njegove naglašene i monumenalističke arhitektonske slike, jasno pokazuju utopijski karakter realističkog "sna", ali isto tako, na neki način, njegovu maštovitu moć nastojanja da se izgradi bolji svet.

Pitanje realizma aktuelno je i posle Drugog svetskog rata. Posebno u Italiji realizmi se pretvaraju u alternative savremenoj paradigmi, ni manje ni više utopijski, već otvoreni prema novim postmodernističkim američkim idejama, kao i arhitekturi grupe "Tendenza".

U ovom radu predloženo je pregledno istraživanje realizama dvadesetog veka kao instrumenta koji odražava stanje u arhitekturi: nakon ekscesa postmodernog populizma, razočarenja "Architettura Razionale" i dijalektike rekonstrukcije - dekonstrukcije, izgleda da se ponovo pojavljuje u arhitekturi jedan novi bauk "Realizma" kao način reagovanja na trenutno arhitektonsko i urbano stanje.

KLJUČNE REČI: UTOPIJA, REALIZAM, ITALIJANSKA ARHITEKTURA POSLERATNOG PERIODA, “TENDENZA”, POSTMODERNIZAM, NOVI REALIZAM, ARHITEKTURA GRADA

\section{(SOC)REALIZMI U PRAKSI: PONOVNO ČITANJE SOVJETSKOG ISKUSTVA IZ TRIDESTIH GODINA PROŠLOG VEKA \\ Alessandro De Magistris}

Diskurs o realizmu u savremenoj arhitektonskoj raspravi izgleda da zaobilazi složenost istorijskih korena ove pojave u arhitekturi dvadesetog veka i, posebno, diskurs o socijalsitičkom realizmu: izvor mnogih perspektiva koje gravitiraju oko ideje realizma u posleratnom periodu i koje predstavljaju značajan momenat u teorijskoj raspravi i projektantskoj praksi između tridesetih i pedestih, sve do Staljinove smrti.

Cilj ovog članka je da predloži jedno artikulisano razmišljanje o iskustvu socrealizma, istraženog u njegovim "formativnim" godinama, u ključnoj fazi njegove razrade. Daleko od toga da je rezultat krutog, teoretskog određenja od vrha nadole, realizam je definisan na pragmatičan način, u većini radova projektanske prakse i teorije. Eklekticizam i pluralizam njegovih izražaja, koji gravitiraju oko ideje kritičke asimilacije istorije, objašnjava razvoj socrealizma između ratnog i posleratnog perioda u SSSR i istočno evropskim zemljama i nalazi svoj najjasniji iskaz u moskovskom metrou. 


\section{MANFREDO TAFURI I KRITIKA REALIZMA}

\section{Luka Skansi}

Jedna od glavnih tema istorijskog rada Manfreda Tafurija, bilo da je analizirao arhitekturu renesanse, iluminizma ili dvadesetog veka, ticala se odnosa između arhitektonskog stvaralaštva i stvarnosti. Ova tema takođe je premisa, odnosno uvodni teorijski okvir, za njegov istorijski i kritički diskurs "kritike realizma", koji je opisan u eseju Architettura e Realismo (Arhitektura i realizam), objavljenom 1985. godine. Ovaj esej predstavlja zaključne Tafurijeve opservacije italijanske posleratne arhitektonske kulture. Neorealizam postaje u njegovom eseju predmet prilično jedinstvene istorijske kontekstualizacije, predmet duboke kritike i, konačno, demistifikacije.

KLJUČNE REČI: ARHITEKTURA, REALIZAM, NEOREALIZAM, KRITIKA, POSLERATNA ITALIJA

\section{FRENK LOJD RAJT, EJN REND I HIPER-KAPITALISTIČKA UTOPIJA}

\section{Tijana Vujošević}

Ovaj rad predstavlja paralelno čitanje Frenk Lojd Rajtovog traktata Iščezavajući grad i Ejn Rendovog romana The Fountainhead. Autorka istražuje retoriku anti-urbanih utopija iz ere Depresije isnspirisanu mitom američkih pionira i osvajanjem granice. Ona identifikuje tri karakteristike Rajtovih i Rendovih anti-urbanih konstrukta: slavljenje muževnosti, poricanje političkog angažmana i anti-intelektualizam, sve to kombinovano u snu prvobitnog, idealnog kapitalizma. Koje su protivrečnosti i nedoslednosti svojstvene u građenju anti-urbane utopije? Ovo je pitanje na koje ovaj rad namerava da odgovori.

KLJUČNE REČI: MODERNIZAM, UTOPIJSKA FIKCIJA, ANTI-URBANIZAM, USONIA, THE FOUNTAINHEAD -

FAUNTEJNHED, IDEOLOGIJA, MUŠKOST, ANTI-INTELEKTUALIZAM

\section{MESTO [PROSTOR] NE-MESTO \\ Krunoslav Ivanišin}

Čak iako se nikada ne materijalizuju kao zgrade, arhitektonski projekti pripadaju stvarnom svetu. Odvojeno od stvarnog prisustva, ali bez lišavanja merljivih prostornih osobina, ovi skupovi tehničkih crteža u srazmeri, opisa i proračuna objašnjavaju buduću fizičku relanost u pogledu prostora, materijalnosti i forme, sa ciljem stvaranja sveta bar malo boljeg nego što je onaj iz koga potiču. Topografski izazovno, divno mesto pored mora; neko specifično gusto urbano okruženje; intrigantan način razmišljanja : neposredni kontekst prethodi i prati stvarnu izgradnju arhitektonskog dela. To je očigledna činjenica sama po sebi koju istoricističke konceptualizacije i klasifikacije ne mogu da poreknu. UTOPIJSKI ili REALISTIČNI, arhitektonski projekti su po svojoj prirodi vezani za mesta. Samo mera njihovog mešanja i uplitanja sa tim mestima može da varira. U našem post-globalizovanom svetu, i utopijski i realistični kvaliteti se mogu naći u projektima koji su hiperrealistični prema neposrednom kontekstu i koji se kontekstima bave minimalno, samo u pogledu raspoređivanja opterećenja, prilagođavanja stvarnoj topografiji, ili klimatskoj zaštiti.

KLJUČNE REČI: MESTO, ARHITEKTA, PROJEKAT, MATERIJAL, [PROSTOR], KONTEKTS, ARHITEKTURA, NE- MESTO 